\title{
ANALISIS PENGARUH ORIENTASI PASAR, ORIENTASI PEMBELAJARAN TERHADAP INOVASI PRODUK, DAN KINERJA PEMASARAN \\ (Studi pada Sentra Industri Kecil Rumah Tangga Kerajinan Anyaman Pandan di Desa Grenggeng Kecamatan Karanganyar Kabupaten Kebumen)
}

\author{
Gunarso Wiwoho, SE, MM
}

\begin{abstract}
ABSTRAKSI
Permasalahan yang dihadapi oleh sebagian banyak industri rumah tangga yaitu kurangnya pengetahuan akan mengelola usaha dan bagaimana memajukan usaha. Dalam membuat inovasi produk, suatu perusahaan harus memperhatikan orientasi pasar dan orientasi pembelajaran, sebab pengetahuan tentang orientasi pasar dan orientasi pembelajaran merupakan kunci sukses inovasi produk yang akan dihasilkan yang kemudian akan berpengaruh pada kinerja pemasaran. Tujuan dari penelitian ini adalah untuk menguji apakah ada pengaruh dari peran orientasi pasar, orientasi pembelajaran, terhadap inovasi produk dan kinerja pemasaran.

Populasi yang dipilih dalam penelitian ini yaitu pemilik industri kecil rumah tangga kerajinan anyaman pandan di Desa Grenggeng Kecamatan Karanganyar Kabupaten Kebumen yang terdiri dari 30 responden, dengan menggunakan penelitian populasi atau populasi studi sensus. Pengumpulan data menggunakan kuisioner dengan jawaban ST (Sangat Setuju), S (Setuju), TS (Tidak Setuju), dan STS (Sangat Tidak Setuju). Data analisis dengan bantuan program SPSS 18.00 dilakukan melalui uji validitas, reliabilitas, dan analisis jalur. Hasil Analisis yang dihasilkan yaitu secara langsung variabel orientasi pasar dan orientasi pembelajaran mempunyai pengaruh signifikan dan positif terhadap inovasi produk namun, tidak mempunyai pengaruh signifikan terhadap kinerja pemasaran Industri kecil rumah tangga kerajinan anyaman pandan dan secara tidak langsung variabel orientasi pasar dan orientasi pembelajaran mempunyai pengaruh signifikan terhadap inovasi produk. Begitu juga orientasi pasar, orientasi pembelajaran, dan inovasi produk sebagai variabel intervening mempunyai pengaruh signifikan terhadap kinerja pemasaran industri kecil rumah tangga kerajnan anyaman pandan.
\end{abstract}

\section{Kata Kunci: Orientasi Pasar, Orientasi Pembelajaran, Inovasi Produk, dan Kinerja Pemasaran}

Kabupaten Kebumen merupakan daerah yang memiliki beragam potensi untuk dikembangkan, baik dalam bidang pariwisata, pertanian, peternakan, makanan maupun kerajinan. Terdapat 449 Desa yang menghiasi wajah Kabupaten yang berslogan "Beriman” ini. Kemajuan perekonomian setiap daerah tidaklah lepas dari peran industri kecil yang berada pada perdesaan, begitu halnya dengan Kabupaten Kebumen yang mempunyai visi modern, berkepribadian, makmur dan sejahtera. 
Keberadaan Industri Kecil Rumah Tangga (IKRT) atau lebih dikenal dengan home industri, selama ini hanya dipandang sebelah mata oleh berbagai pihak. Terbukti ketika disahkannya perjanjian AFTA yang menjatuhkan begitu bayak industri kecil di Indonesia, namun belum ada penanganan serius yang dilakukan oleh pemerintah untuk menangani hal tersebut. Masuknya pengusaha asing dengan bangunanbangunan mewahnya disepanjang jalan, justru menjadi kebanggaan bagi sebagian banyak orang yang melihat. Berbanding terbalik dengan keadaan IKRT yang kebanyakan berada di desa-desa yang tak terlihat keberadaanya, dan produknya justru tidak diminati oleh daerahnya sendiri.

$\begin{array}{ccc}\text { Kenyataannya } & \text { IKRT } & \text { justru } \\ \text { menyerap banyak } & \text { tenaga } & \text { kerja. }\end{array}$ Kecenderungan menyerap banyak tenaga kerja umumnya membuat banyak IKRT juga intensif dalam menggunakan sumber daya alam lokal. Apalagi karena lokasinya banyak di perdesaan, pertumbuhan IKRT akan menimbulkan dampak positif terhadap peningkatan jumlah tenaga kerja, pengurangan jumlah kemiskinan, pemerataan dalam distribusi pendapatan, dan pembangunan ekonomi di perdesaan.
Dari sisi kebijakan, IKRT jelas perlu mendapat perhatian karena tidak hanya memberikan penghasilan bagi sebagian besar angkatan kerja Indonesia, namun juga merupakan ujung tombak dalam upaya pengentasan kemiskinan. Di perdesaan, peran penting IKRT memberikan tambahan pendapatan bagi pengembangan industri dan sebagai pelengkap produksi pertanian bagi penduduk miskin. Boleh dikata, ia juga berfungsi sebagai strategi mempertahankan hidup (survival strategy) di tengah krismon.

Kebumen mempunyai potensi kerajinan yang menjadi ciri khas daerah, yaitu kerajinan pandan. Begitu banyak produk yang dihasilkan dari kerajinan ini antara lain tas, aksesoris, dompet, dan banyak lagi perlengkapan rumah tangga lainnya. Desa Grenggeng Kecamatan Karanganyar terkenal dengan centra IKRT kerajinan pandan. Data dari Dinas Perindustrian, Perdagangan, dan Koprasi (Disperindagkop) Kabupaten Kebumen Tahun 2010 menunjukan jumlah IKRT yang berada di Desa Grenggeng mencapai 256 unit usaha dengan tingkat penyerapan tenaga kerja 632 orang.

\section{Data Sentra Industri Kecil Rumah Tangga Kerajinan Anyaman Pandan Tahun 2010 di Kabupaten Kebumen}

\begin{tabular}{|c|l|l|l|l|}
\hline Nama Sentra & \multicolumn{1}{|c|}{ Desa } & \multicolumn{1}{|c|}{ Kecamatan } & Unit Usaha & $\begin{array}{c}\text { Tenaga } \\
\text { Kerja }\end{array}$ \\
\hline IK Complong, Tas,dll & Wonorejo & Karanganyar & 230 & 486 orang \\
& Pohkumbang & Karanganyar & 212 & 438 orang \\
& Grenggeng & Karanganyar & 256 & 632 orang \\
\hline
\end{tabular}

Sumber: Dinas Perindustrian, Perdagangan, dan Koprasi (Perindagkop) Kabupaten Kebumen Tahun 2010.

Dari data tersebut tergambarkan bahwa, permasalahan yang dihadapi oleh sebagian banyak industri rumah tangga yaitu kurangnya pengetahuan akan 
mengelola usaha dan bagaimana memajukan usaha. Dalam membuat inovasi produk, suatu perusahaan harus memperhatikan orientasi pasar dan orientasi pembelajaran, sebab pengetahuan tentang orientasi pasar dan orientasi pembelajaran merupakan kunci sukses inovasi produk yang akan dihasilkan. Kohli dan Jaworski (Hurley dan Hult dalam Tesis Adi Sismanto, 2006) mendefinisikan orientasi pasar sebagai pencipta kecerdasan pasar (Market Intellingent) dilihat organisasi yang memahami kebutuhan konsumen pada saat ini dan masa yang akan datang, penyebaran kecerdasan di antara departemen dan daya tanggap organisasi secara menyeluruh, sedangkan konsep orientasi pembelajaran menurut Baker and Sinkula dalam tesis Adi Sismanto adalah meningkatkan sekumpulan nilai organisasi yang mempengaruhi kecenderungan perusahaan untuk menciptakan serta menggunakan pengetahuan proses budaya yang berorientasi pasar dan pembelajaran tersebut. Baker dan Sinkula dalam Adi Sismanto penelitiannya menunjukkan bahwa orientasi pasar secara signifikan berhubungan dengan kinerja perusahaan. Sedangkan Han et al dalam Adi Sismanto menyatakan bahwa orientasi pasar berpengaruh positif tetapi tidak signifikan terhadap kinerja, akan tetapi dalam penelitiannya tersebut dinyatakan bahwa orientasi pasar berpengaruh signifikan terhadap kinerja melalui inovasi sebagai variabel intervening. Lebih lanjut Lukas et al (1996) dalam Farrel (2000) menyatakan bahwa pembelajaran dianggap oleh peneliti sebagai kunci untuk menuju sukses organisasi dimasa yang akan datang. Pandangan ini berbeda dengan teori neoklasik yang berpendapat bahwa aset, tanah, tenaga kerja dan modal sebagai unsur kunci produktivitas, Sedangkan Hunt dan Morgan dalam Farrel (2000) juga berpendapat bahwa informasi dan pengetahuan adalah unsur-unsur kunci yang sukses. Baker dan Sinkula dalam Adi Sismanto menyatakan hubungan yang positif dan signifikan antara orientasi pembelajaran terhadap kinerja perusahaan, hal yang sama juga diungkapkan dalam penelitian Farrel (2000), Day (1994), Dikson (1996) dan Stata (1992 dalam Baker dan Sinkula, 1999) sementara itu Stata (1989 dalam Adi Sismanto, 2006) menyatakan bahwa orientasi pembelajaran merupakan kunci dari inovasi.

Dorongan pengetahuan tentang bagaimana strategi untuk mengembangkan usaha dan bertahan di pasar ternyata menjadi kebutuhan utama yang harusnya dimiliki oleh home industri yang ada. Pentingnya pengetahuan akan pemahaman orientasi pasar dan orintasi pembelajaran merupakan hal yang sangat dasar namun menjadi cara strategis suatu IKRT untuk dapat menciptakan produk yang diinginkan oleh konsumen dan meningkatkan inovasi produk yang mereka hasilkan. Dengan pemahaman akan keinginan pasar diharapkan IKRT mampu bersaing dipasaran. Hal ini sejalan dengan misi pemerintah kabupaten Kebumen dalam mengoptimalkan pengelolaan dan pemanfaatan potensi daerah untuk kemakmuran rakyat, juga memperluas jaringan sosial ekonomi secara nasional maupun internasional demi kesejahteraan rakyat. 
Metode Analisis

Karakteristik populasi dalam penelitian ini adalah 30 industri kecil rumah tangga kerajinan anyaman pandan di desa Grenggeng Kecamatan Karanganyar Kabupaten. Dalam penelitian ini teknik pengambilan responden dilakukan dengan metode total sampling yakni seluruh populasi menjadi anggota yang akan diamati sebagai sampel. Persyaratan khusus untuk menjadi sampel penelitian ini adalah:

1) Dalam penelitian ini hanya dibatasi pada industri kecil rumah tangga (IKRT) yang memproduksi kerajinan anyaman pandan dan perusahaan telah berusia minimal 3 (tiga) tahun.

2) Penelitian dikhususkan pada pemilik IKRT kerajinan anyaman pandan di Desa Grenggeng Kecamatan Karanganyar Kabupaten Kebumen.

Dalam penelitian ini untuk menganalisis data menggunakan bantuan program SPSS for windows versi 18.0. Teknik analisis data yang akan digunakan dalam penelitian ini adalah sebagai berikut: uji instrument meliputi uji validitas dan reliabilitas, dengan Alpha Cronbach > 0,6. Uji asumsi klasik terdiri dari uji normalitas, heteroskedastisitas dan multikolinearitas.

Model Jalur Persamaan Struktural

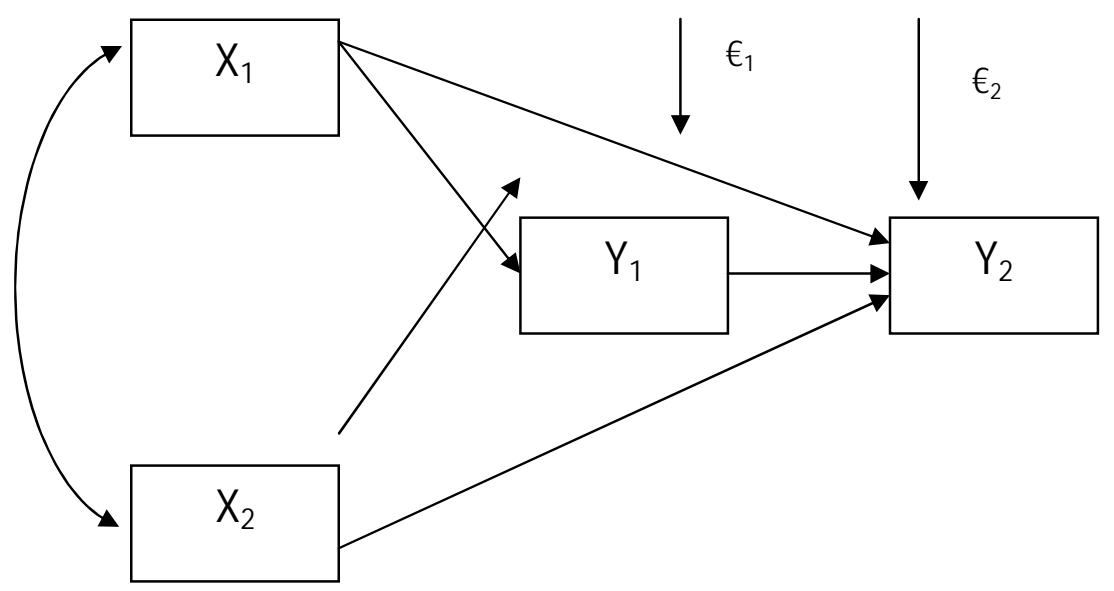

Diagram Jalur diatas terdiri atas dua persamaan struktural, dimana $X_{1}$ dan $X_{2}$ adalah variabel eksogen dan $Y_{1}$ serta $Y_{2}$ adalah variabel endogen. Persamaan Strukturalnya dapat dilihat sebagai berikut:

$\mathrm{Y}_{1}=\mathrm{PY}_{1} \mathrm{X}_{1}+\mathrm{PY}_{1} \mathrm{X}_{2}+€_{1}($ Persamaan Substruktur 1)

$\mathrm{Y}_{2}=\mathrm{PY}_{2} \mathrm{X}_{1}+\mathrm{PY}_{2} \mathrm{Y}_{1}+\mathrm{PY}_{2} \mathrm{X}_{2}+€_{2}($ Persamaan Substruktur 2)

Dimana $\mathrm{Y}_{1}=$ Inovasi Produk

$\mathrm{X}_{1}=$ Orientasi Pasar

$\mathrm{X}_{2}=$ Orientasi Pembelajaran

$\mathrm{Y}_{2}=$ Kinerja Pemasaran

$€=$ Error 
a. Penghitungan Pengaruh Langsung (Direct Effect/DE)

Untuk menghitung pengaruh langsung atau DE, digunakan formula sebagai berikut:

1) Pengaruh variabel orientasi pasar terhadap inovasi produk

$$
\mathrm{X}_{1} \longrightarrow \mathrm{Y}_{1}
$$

2) Pengaruh variabel orientasi pembelajaran terhadap inovasi produk

$$
\mathrm{X}_{2} \longrightarrow \mathrm{Y}_{1}
$$

3) Pengaruh variabel orientasi pasar terhadap kinerja pemasaran

$$
\mathrm{X}_{1} \longrightarrow \mathrm{Y}_{2}
$$

4) Pengaruh variabel orientasi pembelajaran terhadap kinerja pemasaran

$$
\mathrm{X}_{2} \longrightarrow \mathrm{Y}_{2}
$$

5) Pengaruh variabel inovasi produk terhadap kinerja pemasaran

$$
\mathrm{Y}_{1} \longrightarrow \mathrm{Y}_{2}
$$

b. Penghitungan Pengaruh Tidak Lansung (Indirect Effect/IE)

Untuk menghitung pengaruh tidak langsung atau IE, digunakan formula sebagai berikut:

1) Pengaruh variabel orientasi pasar terhadap inovasi produk melalui kinerja pemasaran

$$
\mathrm{X}_{1} \longrightarrow \mathrm{Y}_{1} \longrightarrow \mathrm{Y}_{2}
$$

2) Pengaruh variabel orientasi pembelajaran terhadap inovasi produk melalui kinerja pemasaran

$$
\mathrm{X}_{2} \longrightarrow \mathrm{Y}_{1} \longrightarrow \mathrm{Y}_{2}
$$

c. Pengaruh Total (Total Effect)

1) Pengaruh variabel orientasi pasar terhadap kinerja pemasaran melalui inovasi produk

$$
\mathrm{X}_{1} \longrightarrow \mathrm{Y}_{\mathrm{r}} \longrightarrow \mathrm{Y}_{2}
$$

2) Pengaruh variabel orientasi pembelajaran terhadap kinerja pemasaran melalui inovasi produk

$$
\mathrm{X}_{2} \longrightarrow \mathrm{Y}_{1} \longrightarrow \mathrm{Y}_{2}
$$

3) Pengaruh variabel orientasi pasar terhadap kinerja pemasaran

$$
\mathrm{X}_{\longmapsto} \longmapsto \mathrm{Y}_{2}
$$

4) Pengaruh variabel orientasi pembelajaran terhadap kinerja pemasaran

$$
\mathrm{X}_{2} \longrightarrow \mathrm{Y}_{2}
$$

5) Pengaruh variabel inovasi produk terhadap kinerja pemasaran

$$
\mathrm{Y}_{\longmapsto} \longmapsto \mathrm{Y}_{2}
$$


Grenggeng adalah salah satu Desa yang berada di Kecamatan Karanganyar Kabupaten Kebumen, Provinsi Jawa Tengah, Indonesia. Data dari kantor kepala desa Grenggeng tahun 2011 tercatat Jumlah penduduk sebesar 6.872 jiwa. Kebanyakan warga berprofesi sebagai pengrajin anyaman pandan, terlihat ada 256 unit usaha yang telah berdiri di desa yang terkenal sebagai centra industria anyaman pandan ini. Cakupan wilayah desa Grenggeng meliputi 20 dusun yang tersebar di 10 RW dan 42 RT.

\section{Gambaran Umum Produk Kerajinan Anyaman Pandan}

Anyaman merupakan proses menyilangkan bahan-bahan tumbuhtumbuhan untuk dijadikan satu rumpun yang kuat agar dapat digunakan. Bahanbahan tumbuhan yang dapat dianyam ialah lidi, rotan, akar, pandan, dan sebagainya. Bahan ini biasanya mudah dikeringkan dan lembut. Menganyam adalah salah satu seni tradisi tertua di dunia. Konon kegiatan itu ditiru manusia dari cara burung menjalin ranting-ranting menjadi bentuk yang kuat. Kesenian ini juga ada di berbagai budaya Nusantara. Di Desa Grenggeng Kecamatan Karanganyar Kabupaten Kebumen, Jawa Tengah kegiatan menganyam menjadi pemandangan sehari-hari yang dilakukan masyarakat setempat umumnya ibu-ibu. Tak heran bila desa itu disebut sebagai sentra industri kerajinan anyaman pandan.

Menurut Djumarnah perintis anyaman $\begin{array}{lllllll}\text { pandan warga } & \text { RT } & 1 & \text { RW } & 7 & \text { Desa }\end{array}$ Grenggeng, bahwa semula pengrajin menganyam pandan untuk membuat wadah rokok lintingan (slepen) dan caping (tudung) saja, lantas berkembang setelah Djumarnah kedatangan tamu dari Jakarta, H. Saleh yang memesan anyaman berbentuk sarung bantal berukuran $50 \mathrm{~cm}$ x $50 \mathrm{~cm}$ kemudian dia bersama para ibu mengerjakan pesanan yang disebut complong. Kini motif yang ditawarkan sudah berbeda, yang semula hanya motif beras wutah sekarang berkembang dengan banyak motif tuturnya. (Arif Widodo dalam website suaramerdeka, 2012)

\section{Jenis-jenis/varian dari motif anyaman pandan}

\begin{tabular}{|l|l|l|}
\hline \multicolumn{1}{|c|}{ Biasa } & \multicolumn{1}{|c|}{ Kepang } & \multicolumn{1}{c|}{ Bintulu } \\
\hline a. Beras wutah & & \\
b. Gambir Sekerek & & \\
c. Bata Rubuh & a. Mata deruk & a. Bintulu natural \\
d. Es Lilin & b. Bintang & b. Bintulu warna \\
e. Kaloran & c. Sasak & \\
f. Kembang cengkeh & & \\
g. Kedelen & & \\
h. Tampolan & & \\
\hline
\end{tabular}

Sumber: Muryani (Aktifis UPK PNPM-MD), 2012

Dari macam-macam nama motif diatas merupakan nama yang diberi sendiri oleh masyarakat, dalam perjalanan perkembangan motif-motif dan pemaduan warna anyaman pandan ini ada yang dirancang sendiri oleh masyarakat serta ada pula yang meniru contoh gambargambar dari masyarakat luar Desa. Keahlian masyarakat Desa Grenggeng sudah turun temurun dari nenek moyang, oleh karena itu bagi masyarakat daerah sini untuk belajar menganyam tidak merasa 
sulit, bagi mereka menganyam sudah menjadi makanan pokok sehari-hari.

\section{Karakteristik Responden berdasarkan Alamat}

Berdasarkan hasil penelitian yang telah dilakukan terhadap 30 responden, maka dapat diidentifikasikan mengenai karakteristik responden sebagai berikut :

\section{Klasifikasi Responden Berdasarkan Alamat}

\begin{tabular}{|c|l|c|c|}
\hline No & \multicolumn{1}{|c|}{ Dusun/RW } & Frekuensi & Prosentase \\
\hline $\mathbf{1}$ & Bodeh & 8 & $26,7 \%$ \\
\hline $\mathbf{2}$ & Pancasan & 1 & $3,3 \%$ \\
\hline $\mathbf{3}$ & Beji & 2 & $6,7 \%$ \\
\hline $\mathbf{4}$ & Clungup & 1 & $3,3 \%$ \\
\hline $\mathbf{5}$ & Gintung & 4 & $13,3 \%$ \\
\hline $\mathbf{6}$ & Madeno & 4 & $13,3 \%$ \\
\hline $\mathbf{7}$ & Rowakawuk & 6 & $20 \%$ \\
\hline $\mathbf{8}$ & Stonakunci & 3 & $10 \%$ \\
\hline $\mathbf{9}$ & Pesimpar & 1 & $3,3 \%$ \\
\hline & Total & $\mathbf{3 0}$ & $\mathbf{1 0 0 \%}$ \\
\hline
\end{tabular}

Sumber : Data Primer Diolah

Berdasarkan tabel IV-3 di atas diketahui bahwa dari 30 responden yang dijadikan sampel 8 orang atau $26,7 \%$ adalah warga dusun Bodeh, 1 orang atau 3,3\% adalah warga dusun Pancasan, 2 orang atau 6,7\% adalah warga dusun Beji, 1 orang atau $3,3 \%$ adalah warga dusun Clungup, 4 orang atau $13,3 \%$ adalah warga dusun Gintung, 4 orang atau 13,3\% adalah warga dusun Madeno, 6 orang atau 20\% adalah warga dusun Rowakawuk, 3 orang atau $10 \%$ adalah warga dusun Stonakunci dan 1 orang atau $3,3 \%$ adalah warga dusun Pesimpar.

\section{Analisis Variabel Kinerja Pemasaran}

\section{Peningkatan Pertumbuhan Pelanggan}

\begin{tabular}{|c|c|c|}
\hline Pertumbuhan Pelanggan & Frekuensi & Prosentase \\
\hline 0 & 22 & $73 \%$ \\
\hline 1 & 3 & $10 \%$ \\
\hline 2 & 4 & $13 \%$ \\
\hline 3 & 1 & $3 \%$ \\
\hline
\end{tabular}

Sumber: Data Primer

Berdasarkan tabel IV-4 di atas diketahui bahwa dari 30 responden yang dijadikan sampel, $73 \%$ atau 22 responden tidak mengalami peningkatan pelanggan, $10 \%$ atau 3 responden mampu meningkatkan 1 pelanggan $13 \%$ atau 4 responden mampu meningkatkan 2 pelanggan, dan $3 \%$ atau 1 
responden mampu meningkatkan hingga 3 pelanggan.

Berdasarkan tabel IV-5 di atas diketahui bahwa dari 30 responden yang dijadikan sampel $43 \%$ atau 13 responden tidak mengalami peningkatan pertumbuhan penjualan, $10 \%$ atau 3 responden mampu meningkatkan penjualan hingga $10 \%, 3 \%$ atau 1 responden mampu meningkatkan hingga $20 \%, 7 \%$ atau 2 responden mampu meningkatkan $8 \%, 3 \%$ atau 1 responden mampu meningkatkan hingga 13\%, 3\% atau 1 responden mampu meningkatkan hingga $14 \%, 3 \%$ atau 1 responden mampu meningkatkan hingga 15\%, $17 \%$ atau 5 responden mampu meningkatkan hingga $17 \%, 3 \%$ atau 1 responden mampu meningkatkan hingga $25 \%, 3 \%$ atau 1 responden mampu meningkatkan hingga $33 \%$, dan $3 \%$ atau 1 responden mampu meningkatkan hingga $40 \%$.

\section{Analisis Statistik}

Analisis data kuantitatif dilakukan untuk mengetahui sejauh mana kelayakan instrument penelitian, dalam hal ini adalah kuesioner, mampu mengukur data dari hasil jawaban responden secara tepat dan konsisten. Pengujian ini dilakukan dengan bantuan program SPSS 18.0 for windows untuk mengetahui validitas dan reliabilitas dan sebelum digunakan sebagai acuan analisis selanjutnya.

Suatu kuesioner dinyatakan valid dan reliabel apabila pertanyaan yang diajukan pada kuesioner tersebut mampu mengungkap sesuatu yang akan diukur oleh kuesioner tersebut. Validitas dan reliabilitas data penelitian ini diukur dengan membandingkan ?h????? dan ?????? Sampel yang digunakan untuk uji kuesioner adalah 30 orang responden, maka derajat kebebasan $(\mathrm{df})=\mathrm{n}-2$, $\mathrm{df}=$ 30-2 = 28. Dengan taraf signifikansi 5\% maka diperoleh angka ?????? sebesar 0,361 . (Junaidi, 2012)

\section{Uji Validitas}

1. Variabel Orientasi Pasar $\left(\mathrm{X}_{1}\right)$

Hasil analisis uji validitas variabel kualitas produk dapat dijelaskan sebagai berikut :

\section{Hasil Uji Validitas Variabel Orientasi Pasar}

\begin{tabular}{|c|c|c|c|}
\hline Item & ?????? & ?????? & Keterangan \\
\hline ??_1 & 0,867 & 0,361 & Valid \\
\hline$? ? \_\mathbf{2}$ & 0,803 & 0,361 & Valid \\
\hline$? ? \mathbf{3}$ & 0,619 & 0,361 & Valid \\
\hline
\end{tabular}

\section{Sumber : Data Primer}

Dari tabel IV-6 di atas dapat dijelaskan bahwa ?h???? > ??????. Hal ini berarti seluruh pertanyaan yang digunakan dalam variabel orientasi pasar dinyatakan valid.

2. Variabel Orientasi Pembelajaran $\left(\mathrm{X}_{2}\right)$

Hasil anaslisis uji validitas variabel orientasi pembelajaran dapat dijelaskan sebagai berikut : 


\section{Hasil Uji Validitas Variabel Orientasi Pembelajaran}

\begin{tabular}{|c|c|c|c|}
\hline Item & ??????? & ?????? & Keterangan \\
\hline ??_1 & 0,743 & 0,361 & Valid \\
\hline$? ? \_\mathbf{2}$ & 0,843 & 0,361 & Valid \\
\hline$? ? \mathbf{3}$ & 0,671 & 0,361 & Valid \\
\hline
\end{tabular}

\section{Sumber : Data Primer}

Dari tabel IV-7 di atas dapat dijelaskan bahwa ?h???? > ??????. Hal ini berarti seluruh pertanyaan yang digunakan dalam variabel orientasi pembelajaran dinyatakan valid.

3. Variabel Inovasi Produk $\left(?_{1}\right)$

Hasil analisis uji validitas variabel minat beli dapat dijelaskan sebagai berikut :

\section{Hasil Uji Validitas Variabel Inovasi Produk}

\begin{tabular}{|c|c|c|c|}
\hline Item & ?????? & ??? ??? & Keterangan \\
\hline ??_1 & 0,872 & 0,361 & Valid \\
\hline ??_2 & 0,518 & 0,361 & valid \\
\hline ??_3 & 0,869 & 0,361 & valid \\
\hline
\end{tabular}

Sumber : Data Primer

Dari tabel IV-8 di atas dapat dijelaskan bahwa ?h????? > ??? ??. Hal ini berarti seluruh pertanyaan yang digunakan dalam variabel inovasi produk dinyatakan valid.

4. Variabel Kinerja Pemasaran $\left(?_{2}\right)$

Hasil analisis uji validitas variabel Keputusan Pembelian dapat dijelaskan sebagai berikut:

Hasil Uji Validitas Kinerja Pemasaran

\begin{tabular}{|c|c|c|c|}
\hline Item & ?????? & ? ????? & Keterangan \\
\hline ??_1 & 0,729 & 0,361 & valid \\
\hline ??_2 & 0,960 & 0,361 & valid \\
\hline ??_3 & 0,960 & 0,361 & valid \\
\hline
\end{tabular}

Sumber : Data Primer

Dari tabel IV-9 di atas dapat dijelaskan bahwa ?h???? > ?????. Hal ini berarti seluruh pertanyaan yang digunakan dalam variabel kinerja pemasaran dinyatakan valid.

\section{Uji Reliabilitas}

Uji reliabilitas adalah indeks yang menunjukan tingkat kekuatan suatu alat pengukur dapat dipercaya dan diandalkan. Reliabilitas sering diartikan juga sebagai keajegan atau kekonsistenan. Hal ini berarti bahwa suatu alat ukur memiliki reliabilitas sempurna apabila hasil pengukuran diujikan berkali-kali terhadap subyek yang sama selalu menunjukan hasil skor yang sama. Suatu kuesioner dinyatakan reliabel jika jawaban responden terhadap pertanyaan yang digunakan konsisten. Uji reliabilitas berorientasi pada suatu pengertian bahwa kuesioner yang digunakan sebagai alat pengumpul data dan uji reliabilitas dengan menggunakan 
koefisien Cronbach's Alpha dengan alat bantu SPSS.

Suatu item instrument dinyatakan reliable jika Cronbach's Alpha item deleted menunjukan hasil positif dan corrected item-total correlation tidak ada yang negative serta koefisien Cronbach's Alpha lebih besar dari ? pada tabel. Imam
Ghozali (2002:133) Mengatakan bahwa suatu kelompok item-item pertanyaan dinyatakan reliable bilamana angka koefisien alpha $>0.60$. Perhitungan reliabilitas alat ukur penelitian ini dilakukan dengan program SPSS 18.0 for Windows. Berikut ini hasil pengujian reliabilitas instrument penelitian :

\section{Hasil Uji Reliabilitas Variabel penelitian}

\begin{tabular}{|c|l|c|c|}
\hline No & \multicolumn{1}{|c|}{ Variabel } & $\begin{array}{c}\text { Koefisien } \\
\text { Reliabilitas }\end{array}$ & Keterangan \\
\hline $\mathbf{1}$ & Orientasi Pasar & 0,642 & Reliabel \\
\hline $\mathbf{2}$ & Orientasi Pembelajaran & 0,623 & Reliabel \\
\hline $\mathbf{3}$ & Inovasi Produk & 0,627 & Reliabel \\
\hline $\mathbf{4}$ & Kinerja Pemasaran & 0,868 & Reliabel \\
\hline
\end{tabular}

Sumber : Data Primer

Berdasarkan tabel diatas hasil analisis dapat dijelaskan bahwa seluruh pertanyaan yang digunakan dalam variabel dinyatakan reliable (andal) dan dapat kita lihat pada tabel koefisien Cronbach's Alpha yang nilainya $>0,60$.

\section{Uji Normalitas Data}

Analisis ini untuk menguji apakah data sebuah model regresi, variabel dependen, variabel independen/keduanya mempunyai distribusi normal/mendekati normal. Adapun hasil analisis diperoleh sebagai berikut :

\section{Uji Normalitas 1}

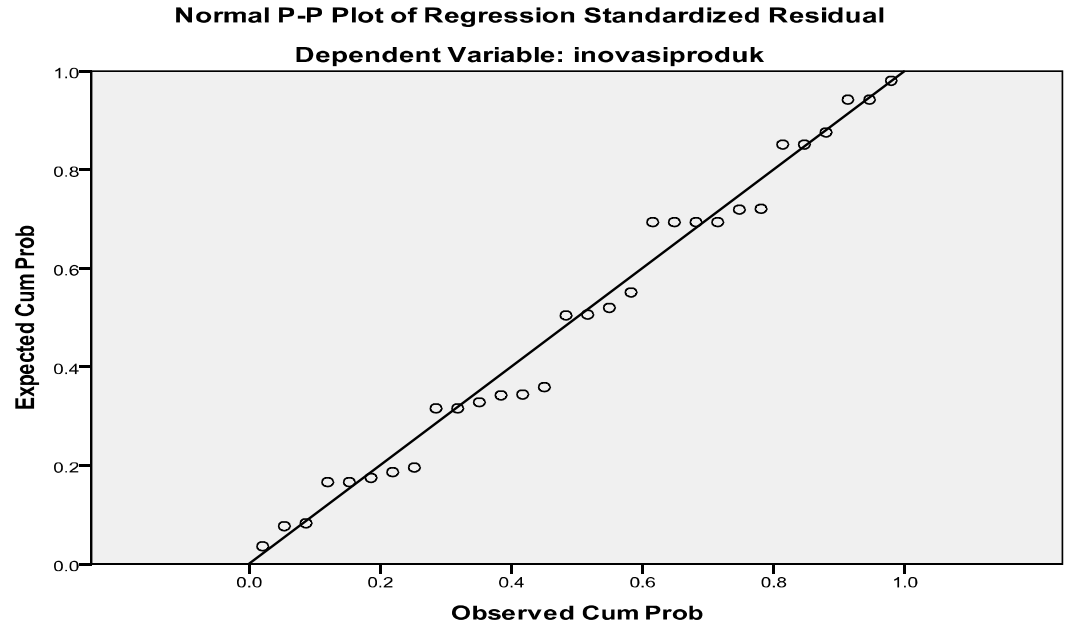




\section{Uji Normalitas 2}

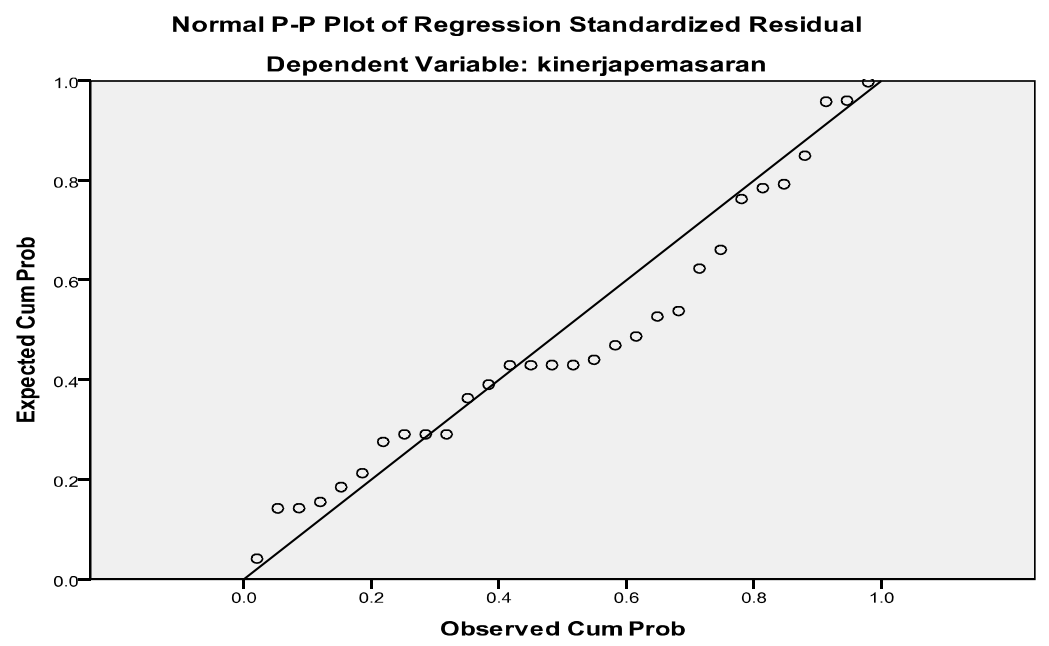

Berdasarkan gambar grafik uji normalitas terlihat bahwa data menyebar disekitar garis diagonal dan mengikuti arah garis diagonal. Maka model regresi memenuhi asumsi normalitas.

\section{Uji Multikolonieritas}

maka dinamakan multikolonieritas. Untuk mendeteksi terdapat tidaknya multikolonieritas didasarkan pada nilai VIF dan tolerance. Dengan kriteria pengambilan keputusan sebagai berikut:

Uji asumsi ini bertujuan untuk menguji apakah pada model regresi ditemukan adanya korelasi diantara variabel independen. Jika ada korelasi,

1. Mempunyai nilai VIF diatas angka 10

2. Mempunyai angka tolerance dibawah 0,10

Berikut hasil pengujian multikolinieritas variabel penelitian :

??????????? 1

\begin{tabular}{|l|c|c|}
\hline \multicolumn{1}{|c|}{ Variabel } & Tolerance & VIF \\
\hline Orientasi Pasar & 0,470 & 2,128 \\
\hline Orientasi Pembelajaran & 0,470 & 2,128 \\
\hline
\end{tabular}

????????? ?? 2

\begin{tabular}{|l|c|c|}
\hline \multicolumn{1}{|c|}{ Variabel } & Tolerance & VIF \\
\hline Orientasi Pasar & 0,399 & 2,508 \\
\hline Orientasi Pembelajaran & 0,404 & 2,473 \\
\hline Inovasi Produk & 0,444 & 2,254 \\
\hline
\end{tabular}

Berdasarkan tabel coefficients di atas dapat dijelaskan bahwa pada nilai tolerace menunjukan tidak ada variabel bebas yang memiliki nilai tolerance kurang dari $10 \%$. Hasil perhitungan nilai VIF juga menunjukan hal yang sama tidak ada variabel bebas yang memiliki nilai VIF lebih dari 10. Jadi dapat disimpulkan bahwa tidak ada multikolonieritas antar variabel bebas dalam model regresi. 


\section{Uji Heterokesdastisitas}

Pengujian ini dilakukan untuk menguji apakah dalam sebuah model regresi terjadi ketidaksamaan varian dan residual disuatu pengamatan ke pengematan yang lain, hasil analisis diperoleh sebagai berikut :

\section{Uji Heterokesdastisitas 1}

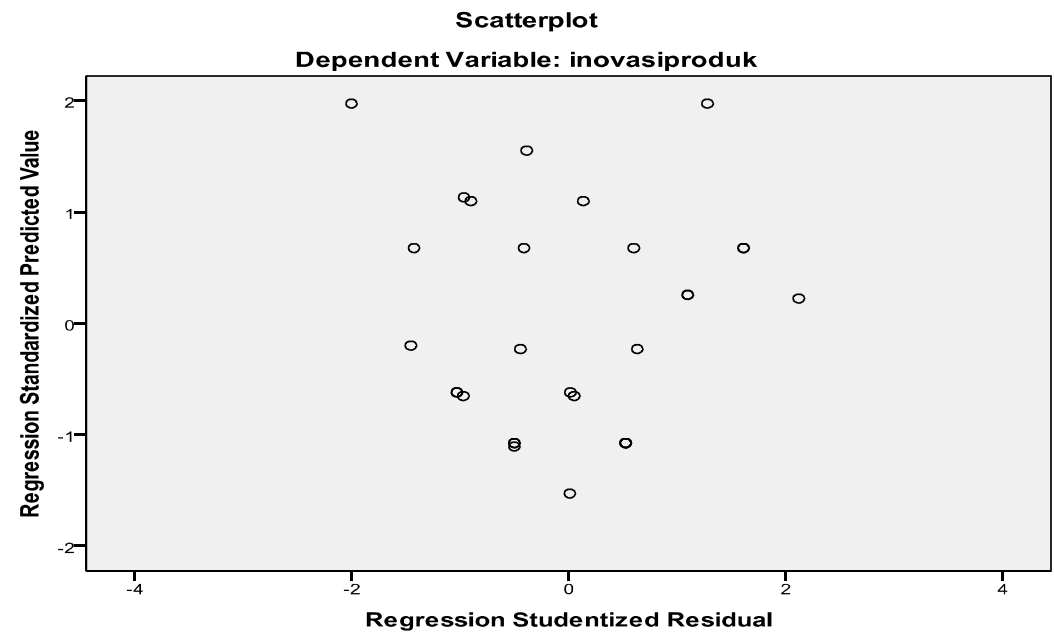

\section{Gambar IV-4}

\section{Uji Heterokesdastisitas 2}

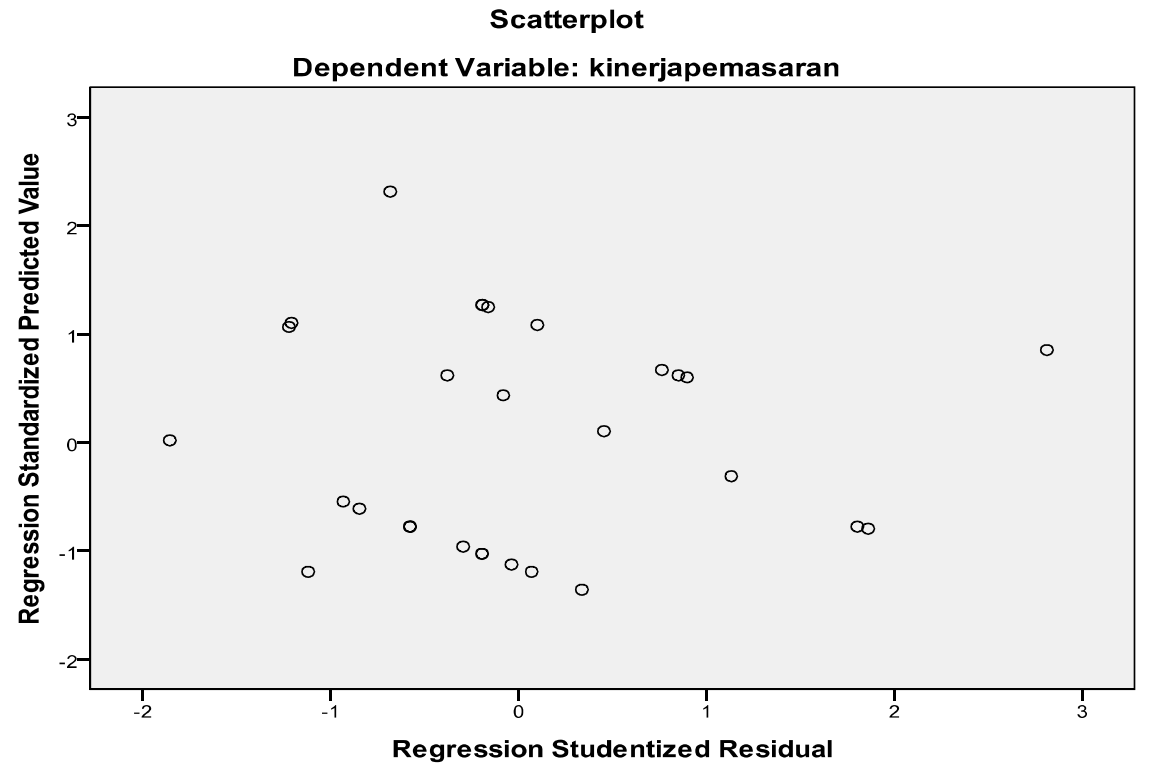

Berdasarkan gambar grafik uji heterokesdastisitas di atas menunjukan bahwa tidak ada pola tertentu, seperti titiktitik (poin) yang membentuk suatu pola tertentu yang teratur (bergelombang, ada pola yang jelas maka dapat disimpulkan model regresi dalam penelitian ini tidak terjadi melebar, kemudian menyempit) dan tidak heterokesdastisitas. 
Analisis Jalur

Persamaan substruktur terdiri dari dua persamaan dimana $?_{1}$ dan $?_{2}$ adalah variabel eksogen; $?_{1}$ dan $?_{2}$ adalah variabel endogen, sehingga diperoleh persamaan struktur sebagai berikut :

$\mathrm{Y}_{1}=\mathrm{PY}_{1} \mathrm{X}_{1}+\mathrm{PY}_{1} \mathrm{X}_{2}+€_{1}($ Persamaan Substruktur 1$)$

$\mathrm{Y}_{2}=\mathrm{PY}_{2} \mathrm{X}_{1}+\mathrm{PY}_{2} \mathrm{Y}_{1}+\mathrm{PY}_{2} \mathrm{X}_{2}+€_{2}($ Persamaan Substruktur 2$)$

Dimana :

$?_{1}=$ Inovasi Produk

$?_{2}=$ Kinerja pemasaran

$?_{1}=$ Orientasi pasar

$?_{2}=$ Orientasi pembelajaran

$1=$ error

Berdasarkan hasil dari perhitungan dengan menggunakan bantuan komputer program SPSS maka dapat dibuat persamaan strukturnya.

Adapun persamaan struktur 1 adalah sebagai berikut :

$?_{?}=\mathbf{0 , 4 1 1} ?{ }_{?}+\mathbf{0 , 3 9 2} ? ?+$ ?

dan persamaan struktur ke-2 adalah sebagai berikut :

$$
?_{?}=\mathbf{0 , 1 6 9} ?_{?}+\mathbf{0 , 5 1 6} ? ?+\mathbf{0 , 2 4 5} ? ?+\text { ? }
$$

Koefisien Determinasi

Untuk melihat kemampuan variabel bebas dalam menerapkan variabel tidak bebas dapat diketahui dari besarnya koefisien determinasi berganda $\left(\mathrm{R}^{2}\right)$. Untuk mengetahui hasil koefisien determinasi berganda $\left(\mathrm{R}^{2}\right)$ dalam penelitian ini dapat dilihat pada tabel berikut ini :

Model ?? ? ???

\begin{tabular}{|c|c|c|}
\hline Model & R Square (1) & R Square (2) \\
\hline 1 & 0.556 & 0.712 \\
\hline
\end{tabular}

Nilai koefisien determinasi $\left(\mathrm{R}^{2}\right)$ persamaan 1 diperoleh 0,556 dapat diartikan variabilitas inovasi produk yang dapat diterangkan dengan menggunakan variabel orientasi pasar dan orientasi pembelajaran sebesar $55,6 \%$, sementara pengaruh sebesar $44,4 \%$ disebabkan oleh variabel-variabel lain diluar model ini. Demikian pula untuk persamaan 2, nilai koefisien determinasi $\left(\mathrm{R}^{2}\right)$ diperoleh 0,712 artinya variabilitas kinerja pemasaran yang dapat diterangkan dengan menggunakan variabel orientasi pasar, orientasi pembelajaran, dan inovasi produk sebesar $71,2 \%$, sementara pengaruh sebesar $28,8 \%$ disebabkan oleh variabel-variabel lain diluar model ini. 


\section{Perhitungan Pengaruh Masing-masing Variabel Pengaruh Langsung (Direct Effect)}

1. Pengaruh variabel orientasi pasar terhadap inovasi produk

$$
?_{1} \rightarrow ?_{1}=0,411
$$

2. Pengaruh variabel orientasi pembelajaran terhadap kinerja pemasaran

$$
?_{2} \rightarrow ?_{1}=0,392
$$

3. Pengaruh variabel orientasi pasar terhadap kinerja pemasaran

$$
?_{1} \rightarrow ?_{2}=0,169
$$

4. Pengaruh variabel orientasi pembelajaran terhadap kinerja pemasaran

$$
?_{2} \rightarrow ?_{2}=0,245
$$

5. Pengaruh variabel inovasi produk terhadap kinerja pemasaran

$$
?_{1} \rightarrow ?_{2}=0,516
$$

\section{Pengaruh Tidak Langsung}

1. Pengaruh variabel orientasi pasar terhadap kinerja pemasaran melalui inovasi produk

$$
?_{1} \rightarrow ?_{1} \rightarrow ?_{2}=(0,411 \times 0,516)=0,212076
$$

2. Pengaruh variabel orientasi pembelajaran terhadap kinerja pemasaran melalui inovasi produk

$$
?_{2} \rightarrow ?_{1} \rightarrow ?_{2}=(0,392 \times 0,516)=0,202272
$$

\section{Pengaruh Total}

Pengaruh variabel orientasi pasar terhadap kinerja pemasaran melalui inovasi produk.

$$
?_{1} \rightarrow ?_{1} \rightarrow ?_{2}=(0,411+0,516)=0,927
$$

Pengaruh variabel orientasi pembelajaran terhadap kinerja pemasaran melalui inovasi produk.

$$
?_{2} \rightarrow ?_{1} \rightarrow ?_{2}=(0,392+0,516)=0,908
$$

Pengaruh variabel orientasi pasar terhadap kinerja pemasaran.

$$
?_{1} \rightarrow ?_{2}=0,169
$$

Pengaruh variabel orientasi pembelajaran terhadap kinerja pemasaran.

$$
?_{2} \rightarrow ?_{2}=0,245
$$

Pengaruh variabel inovasi produk terhadap kinerja pemasaran.

$$
?_{1} \rightarrow ?_{2}=0,516
$$

\section{Analisis Korelasi}

Korelasi antara orientasi pasar dan orientasi pembelajaran

Berdasarkan perhitungan diperoleh angka korelasi antara variable orientasi pasar dan orientasi pembelajaran sebesar 0,728. Untuk menafsir angka tsb digunakan criteria sbb: 


$$
\begin{array}{ll}
0-0,25 & : \text { korelasi sangat lemah (dianggap tidak ada) } \\
>0,25-0,5 & : \text { korelasi cukup } \\
>0,5-0,75 & : \text { korealasi kuat } \\
>0,75-1 \quad: \text { korelasi sangat kuat }
\end{array}
$$

Korelasi sebesar 0,728 mempunyai maksud hubungan antara variable orientasi pasar dan orientasi pembelajaran kuat dan searah(karena hasilnya positif). Searah artinya jika orientasi tinggi maka orientasi pembelajaran juga tinggi. Korelasi dua variable bersifat signifikansi (sig) karena angka signifikansi sebesar $0,000<0,05$.jika angka sig <0,05 maka hubungan kedua variable signifikan, sebaliknya jika angka sig >0,05 maka hub kedua variable tdk signifikan.

Korelasi antara orientasi pasar dan inovasi produk

Berdasarkan perhitungan diperoleh angka korelasi antara variable orientasi pasar dan inovasi produk sebesar 0,696. Korelasi sebesar 0,696 mempunyai maksud hubungan antara variable orientasi pasar dan inovasi produk kuat dan searah. Korelasi dua variable bersifat signifikan karena angka signifikansi sebesar $0,000<0,05$

Korelasi antara orientasi pembelajaran dan inovasi produk

Berdasarkan perhitungan diperoleh angka korelasi antara variable orientasi pembelajaran dan inovasi produk sebesar 0,691 . Korelasi sebesar 0,691 mempunyai maksud hubungan antara variable orientasi pembelajaran dan inovasi produk kuat dan searah. Korelasi dua variable bersifat signifikan karena angka signifikansi sebesar $0,000<0,05$.

\section{DIAGRAM JALUR}

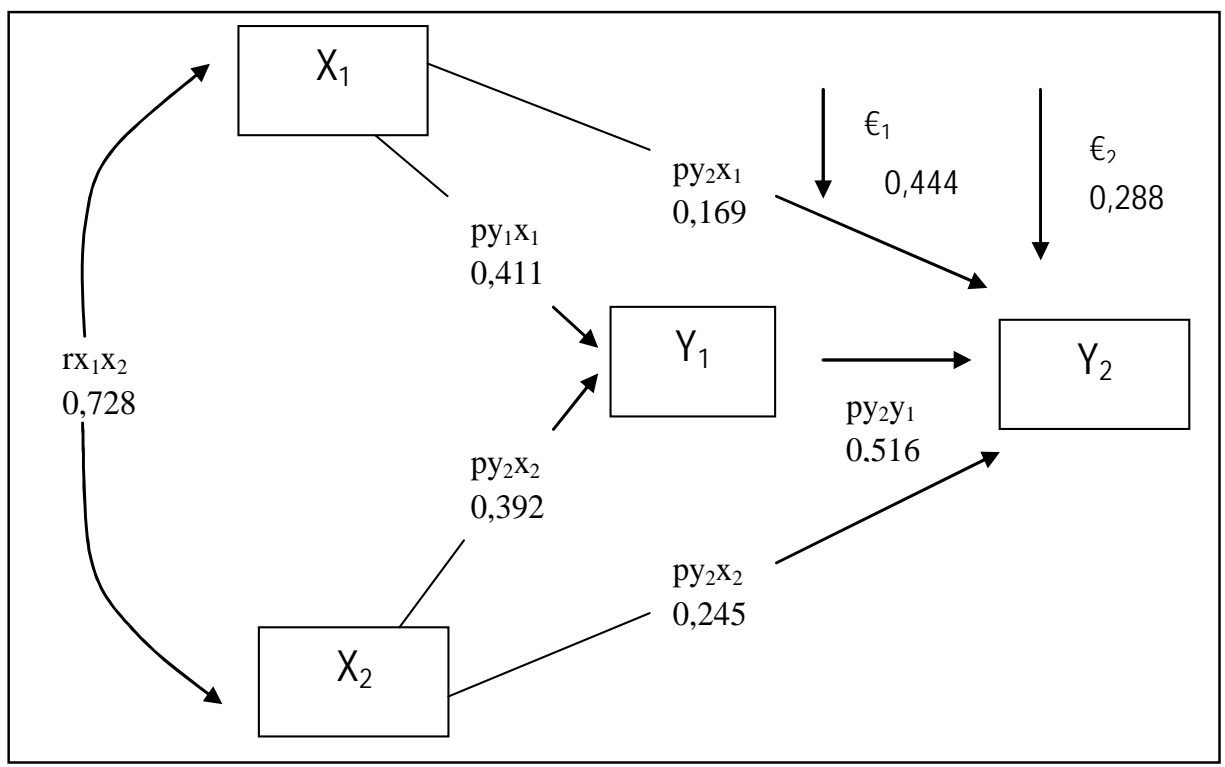

\section{Implementasi Manajrial}

1. Penerapan Strategi Orientasi Pasar dalam IKRT Kerajinan Pandan masih sangat kurang dilakukan. Meskipun sebagian besar pelaku usaha telah memenuhi keinginan dan kebutuhan pelanggan, namun 
hanya sebatas pada pelanggan rutin dan hanya bergantung pada satu atau dua pelanggan potensial, tanpa ada usaha untuk menambah pelanggan dengan memperbanyak inovasi produk yang dihasilkan. Tidak adanya keberanian IKRT dalam menciaptakan produk baru dikarenakan tidak didukung dengan permintaan yang ditawarkan, oleh sebab itu kebanyakan pelaku usaha hanya memproduksi produk sesuai dengan apa yang diinginkan dari pelanggan potensial. Hal inilah yang menyebabkan hasil penelitian bahwa terdapat hubungan linier antara orientasi pasar terhadap inovasi produk, namun tidak terdapat hubungan linier antara orientasi pasar terhadap kinerja pemasaran.

2. Kesadaran pentingnya pembelajaran sebenarnya sudah tertanam pada sebagian besar pelaku usaha yaitu dengan banyaknya pelaku usaha yang mau berpartisipasi dalam platihan-pelatihan yang ada pada waktu tertentu. Keahlian yang dimiliki pelaku usaha tidak diimbangi dengan menambah variasi produk untuk meningkatkan kinerja pemasran. Para pelaku usaha mengaku merasa kesulitan dalam pemasaran produknya jika tidak menuruti model produk sesuai dengan yang diinginkan oleh pelanggan potensial. Oleh karena itu dalam hasil penelitian orientasi pembelajaran memiliki hubungan linier terhadap inovasi produk, namun tidak memiliki hubungan linier terhadap kinerja pemasaran.

\section{Kesimpulan}

Berdasarkan hasil analisis data yang telah dilakukan dapat ditarik beberapa kesimpulan sebagai berikut :

1. Berdasarkan karakteristik responden, bahwa dari 30 responden yang dijadikan sampel yaitu 8 orang warga dusun Bodeh, 1 orang warga dusun Pancasan, 2 orang warga dusun Beji, 1 orang warga dusun Clungup, 4 orang warga dusun Gintung, 4 orang warga dusun Madeno, 6 orang warga dusun Rowakawuk, 3 orang warga dusun Stonakuci dan 1 orang warga dusun Pesimpar.

2. Berdasarkan uji validitas dan reliabilitas menunjukkan bahwa semua butir kuesioner pada variabel orientasi pasar, orientasi pembelajaran, inovasi produk dan kinerja pemasaran dinyatakan valid dan reliable. Kemudian dari hasil uji asumsi regresi berganda semua variabel penelitian tidak memiliki masalah dengan multikolinieritas, heterokesdastisitas dan normalitas sehingga model regresi dapat digunakan.

3. Pengaruh variable orientasi pasar terhadap kinerja pemasaran secara langsung sebesar 0,169

4. Pengaruh variable orientasi pembelajaran terhadap kinerja 
pemasaran secara langsung sebesar 0,245

5. Pengaruh variable inovasi produk terhadap kinerja pemasaran secara langsung sebesar 0,516

6. Pengaruh variable orientasi pasar, orientasi pembelajaran, dan inovasi produk terhadap kinerja pemasaran 0,712

7. Pengaruh variable orientasi pasar terhadap inovasi produk sebesar 0,411

8. Pengaruh variable orientasi pembelajaran terhadap inovasi produk sebesar 0,392

9. Pengaruh faktor orientasi pasar, orientasi pembelajaran secara gabungan terhadap inovasi produk sebesar 0,556

\section{Saran}

Berdasarkan hasil analisis data yang telah dilakukan dapat diberikan beberapa saran sebagai berikut :

1. Meskipun industri kecil rumah tangga kerajinan pandan masih tergolong industri sederhana, namun disarankan untuk memahami orientasi pasar agar dapat memahami kebutuhan dan keinginan pelanggan berkaitan dengan produk yang dihasilkan, memahami kekuatan atau kelebihan yang dimiliki serta kelemahannya agar dapat bersaing dipasaran, serta selalu berkomunikasi antar fungsi untuk mengkoordinasikan kebutuhan pasar.

2. Pengalaman dan keahlian yang telah dimiliki disarankan mampu dikembangkan oleh pelaku usaha agar dapat menambah nilai yang dimiliki industri kecil dari produk yang dibuat. Dengan demikian akan berdampak pada peningkatan kinerja pemasaran.

3. Keterampilan yang telah dimiliki oleh pengrajin anyaman pandan dalam menghasilkan produk-produk baru disarankan agar dikembangkan dan dipasarkan ke pelanggan dalam bentuk barang jadi agar dapat dipasarkan dengan keanekaragaman produk yang diminati oleh konsumen.

4. Bagi Industri kecil rumah tangga disarankan untuk dapat mengembangkan usahanya dengan modal keahlian menganyam yang dimiliki. Dapat mengembangkan inovasi produk anyaman pandan dengan meningkatkan orientasi pasar dan orientasi pembelajaran agar dapat berpengaruh terhadap kinerja pemasaran. 


\section{DAFTAR PUSTAKA}

Andi. 2010. Mudah Belajar Statistik Dengan Spss 18. Yogyakarta: Wahana Komputer

Dinas Perindustrian Perdagangan dan Koprasi Kabupaten Kebumen. 2010. Kebumen

Fatkhul, Mujib Mohammad. 2010. Analisis Faktor-Faktor Yang Berpengaruh Secara Langsung dan Tidak Langsung Terhadap Kinerja Usaha Kecil \& Menengah (UKM) Studi Pada Pelaku UKM di Kabupaten Kebumen. Skripsi Sarjana (Tidak dipublikasikan). Semarang: Fakultas Ekonomi Universitas Diponogoro

Indiantoro, Nur dan Bambang Supomo. 1999. Metodologi Penelitian Bisnis. Edisi pertama. Yogyakarta: BPFE

Inggrit. 2003. Analisis Faktor-faktor yang Mempengaruhi Inovasi Produk untuk Meningkatkan Kinerja Pemasaran (Studi pada Industri Batik di Pekalongan). Tesis Magister Manajemen (Tidak dipublikasikan). Semarang: Program Pascasarjana Universitas Diponogoro

Junaidi. 2011. "Titik Persentase Distribusi t". Diambil dari http://junaidichaniago.wodpress.com diakses tanggal 4 juni 2012.

. 2011. "Titik Persentase Distribusi F (Probabilita=0,05)". Diambil dari http://junaidichaniago.wodpress.com diakses tanggal 4 juni 2012.

2011. “Tabel r (Koefisien Korelasi Sederhana)". Diambil dari http://junaidichaniago.wodpress.com diakses tanggal 4 juni 2012.

Kantor Kepala Desa Grenggeng Kecamatan Karanganyar Kabupaten Kebumen. 2012. Kebumen, Jawa Tengah

Raharjo, Agung. 2006. Analisis Faktor-Faktor Yang Mempengaruhi Inovasi Produk Untuk Meningkatkan Keunggulan Bersaing Dan Kinerja Pemasaran (Studi Pada Industri Batik Skala Besar Dan Sedang Di Kota Dan Kabupaten Pekalongan).). Semarang: Program Pascasarjana Universitas Diponogoro

Sarwono, Jonathan. 2007. Analisis Jalur Untuk Riset Bisnis Dengan Spss. Yogyakarta: ANDI

Soleh, Mohamad. 2008. Analisis Strategi Inovasi dan DampaknyaTerhadap Kinerja Perusahaan (Studi Kasus : UKM Manufaktur Di Kota Semarang). Tesis Magister 
Manajemen (Tidak dipublikasikan). Semarang: Program Magister Manajemen Universitas Diponogoro

Sugiyono. 1999. "Metode Penelitian Bisnis”, Bandung: Alfabeta

Suharsimi, Arikunto. 1996. "Prosedur Penelitian Suatu Pendekatan Praktek”. Jakarta: Rineka Cipta

Tambunan, T.H. Tulus. 2002. Usaha Kecil dan Menengah di Indonesia, Beberapa Isu Penting. Jakarta: Salemba Empat

Widodo, Arif. 2012. "Anyaman Pandan Bernilai Milyaran Rupiah". Diambil dari http://www.suaramerdeka.com/v1/index.php/read/cetak/2012/04/22/184057/Anyaman-

Pandan-Bernilai-Miliaran-Rupiah-. diakses tanggal 8 Mei 2012. 